University of Nebraska - Lincoln

DigitalCommons@University of Nebraska - Lincoln

French Language and Literature Papers

Modern Languages and Literatures, Department

October 1985

\title{
Voltaire's Fables of Discretion: The Conte philosophique in Le Taureau blanc
}

Thomas M. Carr Jr.

University of Nebraska - Lincoln, tcarr1@unl.edu

Follow this and additional works at: https://digitalcommons.unl.edu/modlangfrench

Part of the Modern Languages Commons

Carr, Thomas M. Jr., "Voltaire's Fables of Discretion: The Conte philosophique in Le Taureau blanc" (1985). French Language and Literature Papers. 15.

https://digitalcommons.unl.edu/modlangfrench/15

This Article is brought to you for free and open access by the Modern Languages and Literatures, Department of at DigitalCommons@University of Nebraska - Lincoln. It has been accepted for inclusion in French Language and Literature Papers by an authorized administrator of DigitalCommons@University of Nebraska - Lincoln. 
Published in Studies In Eighteenth-Century Culture, valume 15 (1985), edited by John Conway, pp. 47-65. Cullshed by the American Society for Eighteenth-

Century Studies.

\section{Voltaire's Fables of Discretion: \\ The Conte philosophique in}

\section{Le Taureau blanc}

THOMAS M. CARR, JR.
Je voudrais surtout que, sous le voile de la fable, il laissât entrevoir aux yeux exercés quelque vérité fine qui echappe au vulgaire.

Le Taureau blanc (1774) ${ }^{\ddagger}$ offers remarkable insight into Voltaire's use of the conte as persuasive discourse for two reasons. First, as the purest example of the genre among his last contes, it is in many ways the quintessence of his talents as a conteur. This tale does not cover any new ideological territory in its treatment of the Old Testament, a preoccupation found in much of his production of the Ferney period nor does it introduce any technical innovations. But unlike Voltaire's last tragedies, where his reworking of the themes and dramatic conventions of his dramatic successes of the 1730 s and 1740 s gives the impression of self-parody, his handling of fantasy, irony, and philosophic commentary in Le Taureau blanc remains fresh. Study of this conte, which has been neglected more because its subject excites little passion today than for any flaws, can help us isolate key components of the conte philosophique in a way more problematic contes like Candide or more experimental ones like L'Ingénu cannot. Second, Le Taureau blanc contains some of the most explicit commentary on persuasive discourse to be found in the corpus of his imaginative works. Moreover, the rhetorical situation of the characters within the tale offers certain parallels to Voltaire's own situation as a persuader. An examination of the various modes of persuasive speech, especially narra- 
tive and eloquence, within what might be called his méta-conte, will afford a better understanding of why narrative proved a more effective weapon on behalf of enlightenment in Voltaire's hands than eloquence.

Critics have elucidated the religious significance of this work, showing how Voltaire presents biblical discourse as arising from the same process of fabulation which produced the myths of all ancient cultures. However the political and social setting in which he places this demystification of scripture has been somewhat neglected, even though politics is an essential component of the rhetorical situation within the conte. ${ }^{2}$ Le Taureau blanc explores a gamut of registers available to the would-be sage: prophecy and eloquence, biblical narrative and the moral or philosophical tale, but all of these modes of discourse on display have in common the fact that they are enunciated by courtiers.

In contrast with other tales of Voltaire which take as their setting a Baedeker of Oriental, American, or European lands, if not the galaxies, all the action of this tale unfolds in the confines of the court of Amasis, king of Tanis. While the tale does offer vistas open on the ancient Orient-Babylon, Memphis, Israel-it is only because representatives of these outside worlds make their way to the court of Amasis. Nabuchodonosor, who has been transformed into a white bull, arrives in the custody of the witch of Endor. The priests of Memphis travel in great pomp toward Tanis in search of a replacement for their god-bull who has just died. Finally, the prophets Daniel, Jérémie, and Ezéchiel journey from the Holy Land. All the characters are either royalty like Nabuchodonosor, Amasis, and his daughter, Amaside, or they are courtiers. The sage Mambrès is counsellor to the king and superintendant of the household of the princess. The serpent, who displays a perfect mastery of courtly graces, recalls his reputation as a disgraced favorite (21: 491), a reference to the fall of Lucifer from the celestial court. Even the prophets have less a religious aura than the political character of courtiers; they are presented as ambitious upstarts who covet the rank of their royal masters.

Discretion is the hallmark of all discourse in the court of the superstitious tyrant of Tanis. This discretion involves, on the one hand, the guarded use of language necessitated by an environment where distrust and suspicion are a condition for survival. It also implies the aristocratic exclusiveness (as seen in Amaside's description of the ideal conte) that is the mark of a self-conscious elite eager to preserve its secrets from outsiders it considers unworthy. I would argue that in the course of Voltaire's efforts to promote enlightenment he had to come to terms with similar expectations that all discourse be discreet. In a regime such as that of Louis $\mathrm{XV}$ where discretion was all the more imperative if any criticism of the official ideology was contemplated, eloquence in its enlightened forms could hardly exist.

Amasis' attitude toward language illuminates why discretion is a necessity for all who live in the court of such a despot. His vow to have his daughter executed if she speaks the name of his enemy $\mathrm{Na}$ buchodonosor doubly illustrates the irrevocable nature of the word for him. In his eyes, for Amaside even to pronounce Nabuchodonosor's name is to surrender herself body and soul to the king of Babylon because, for the superstitious Amasis, a word is the reality it is supposed to represent. Likewise, once he has given his word to have her killed if she transgresses his taboo, he cannot gainsay himself. Thus it is not surprising that his advisors tell him only what they think he wants to hear. For example, aware of the king's ire when he learns of his daughter's affection for the white bull, "tous les ministres d'état conclurent que le taureau était un sorcier. C'était tout le contraire" (21: 494). As the princess remarks elsewhere, "tant de ministres ont été punis d'avoir donné de bons conseils" (21: 491). In such a world where the mere enunciation of a word can carry such grave consequences, discretion must mark all discourse. Little wonder that the wise Mambrès suggests that his pupil be wary of the potential indiscretion of her ladies-in-waiting. Indeed, in spite of their devotion to the princess and their promise of silence, they only manage to keep the secret of her interest in the mysterious white bull a single day. Worse, perfidious souls like the crow, "une bête si difficile et si bavarde" (21: 500), stand ready to denounce Amaside when she eventually breaks her father's taboo. Thus Mambrès recommends to the princess the cult of the god Harpocrate, who is presented as the god of discretion. "Vous n'avez pas été élevée dans la sagesse égyp tienne pour ne savoir pas commander à votre langue. Songez qu'Harpocrate, l'un de nos plus grand dieux, a toujours le doigt sur sa bouche" (21: 484). The tale's entire plot turns on this effort to control Amaside's tendency toward indiscretion. During the first part of the conte Mambrès struggles to keep Amaside from uttering her lover's name. In the second part, when the secret is out, he attempts to soften the consequences of her inability to remain silent after her father condemns first the bull and then her to death.

The first comedy of Voltaire, L'Indiscret (1725) had already brought a similar analysis of indiscretion to the stage. The court in this play, "ce lieu tout rempli d'injustice," "ce dangereux séjour" (2: 247-48) could almost be that of Amasis. In L'Indiscret we find the same warn- 
ing against feminine indiscretion, the same stress on the absence of freedom of expression at court, the same advice to hold back secrets. However, $L$ 'Indiscret only deals with discretion in the context of fashionable Parisian society where a young fop loses his amorous conquests by bragging too loudly about them. In the court of Amasis, discretion was a matter of life and death, a situation not without parallel to that of a philosophe like Voltaire who challenged the ideology of the Ancien Régime.

Before proceeding further, some reflections on the notion of discretion can be useful. While in its broadest sense, discretion implies prudence in both action and speech, only discreet discourse is at issue here. Such discretion is ultimately a defensive strategy, motivated by fear that full and open disclosure will in some way leave a speaker vulnerable. The audience is the enemy. Thus discretion commonly involves some degree of self-censorship ranging, on the one hand, from partial disclosure to the extreme of absolute silence. An alternate form of this self-censorship is to conceal not so much what the speaker believes as the speaker's identity. Rather than seek selfprotection by censoring discourse itself, such discreet speakers make use of stratagems such as a pseudonym or anonymous publication to speak their mind while not revealing their name. They suppress their identity, not their thoughts. At the other extreme from such tactics involving some degree of silence we find another mode of address that might loosely be labeled discreet-effusive flattery. A flatterer speaks openly and publicly but at the loss of the congruence that should exist between one's self-identity as a speaker and one's discourse. Rather than enunciate what they truly believe, such speakers allow the expectations of their audience to become their norm.

Two broad categories of persuasive discourse can be distinguished within Le Taureau blanc, the first centering around eloquence and the second around narrative. Both are conditioned by the requirements of discretion, and Voltaire's handling of both within the conte sheds light on how he adapted his own discourse to the discretion imposed by eighteenth-century expectations.

Voltaire was well aware of the old rhetorical topos ${ }^{3}$ on the incompatibility of true eloquence and lack of freedom. He wrote in an article prepared for the Encyclopédie, "L'éloquence sublime n'appar- tient, dit-on, qu'à la liberté: c'est qu'elle consiste à dire des vérités hardies, à étaler des raisons et des peintures fortes. Souvent un maître n'aime pas la vérité, craint les raisons, et aime mieux un compliment délicat que de grands traits" ("Eloquence," 18: 516). Without a free forum, discretion smothers true eloquence. In Le Taureau blanc Voltaire presents two forms of such false eloquence; the first is the empty verbiage of the Hebrew prophets, the second is the courtly eloquence best exemplified by the serpent, but also practiced to some extent by Mambrès.

Voltaire assimilates prophecy to defective eloquence by portraying the prophets as verbose buffoons, whose figured style conceals an absence of solid reasoning. Prophecy is reduced to the ability to manipulate a splendid, although empty eloquence. "Ezéchiel et Jérémie parlèrent aussi très-longtemps dans un fort beau style qu'on pouvait à peine comprendre" (21: 503). The variants of the last chapter point out the precise path the prophets must follow to practice true eloquence: "on leur enjoignit seulement de parler moins et de parler mieux." 4 Of course, their garrulous discourse is neither innocent nor harmless. For Voltaire, the prophets are ambitious political upstarts who aspire to privileges of their royal masters. Sprung from the people, their false eloquence is a means of self-promotion. Elsewhere Voltaire describes them as demagogues, bent on deceiving the people. ${ }^{5}$ In $L e$ Taureau blanc, where Nabuchodonosor's metamorphosis into a bull is presented as the work of Daniel, the accent is on the danger they pose for their sovereigns.

Given this natural enmity between the monarch and prophets, it is not surprising that Daniel, Ezéchiel, and Jérémie are attacked by $\mathrm{Na}$ buchodonosor who is enraged to find that they can discourse so freely while he is deprived of language and imprisoned in the body of a bull. The three are only saved from death when they are themselves transformed into chattering magpies. Mambrès reads into this metamorphosis a lesson of discretion: the empty eloquence of the prophets must give way to a wisdom that never forgets to be discreet. "Ce nouvel incident produisait de nouvelles réflexions dans l'esprit du sage Mambrès. 'Voilà, disait-il, trois grands prophètes changés en pies: cela doit nous apprendre à ne pas trop parler, et à garder toujours une discrétion convenable.' Il concluait que sagesse vaut mieux qu'éloquence" (21: 503).

The courtly eloquence of Mambrès and the serpent is, in a sense, more discreet than the pompous eloquence of prophecy, but only because it is controlled by a worldly wisdom that has less regard for truth than for what its audience wants to hear. As we have seen in 
the article "Eloquence," Voltaire had noted the preference of tyrants for flattery over authentic eloquence. In fact, he singles out oriental oratory designed to flatter some despot as being particularly prone to hyperbole: "Les Orientaux étaient presque tous esclaves: c'est un caractère de la servitude de tout exagérer: ainsi l'éloquence asiatique fut monstrueuse" (18: 515). This use of exaggeration makes courtly eloquence a close relative of the figure-laden style of prophecy.

In Le Taureau blanc the serpent is the acknowledged master of this rhetoric of flattery. The princess identifies his talent with the art of pleasing: "vous avez le talent de persuader tout ce que vous voulez, et c'est régner que de plaire" (21: 491). Yet the danger that such a rhetoric can pose for its public is seen in the consequences for the princess of her dealings with the serpent. Even though he insists that he only wants to please and aid her, after each interview with him she moves one syllable closer to uttering the complete name of her lover and bringing down upon herself her father's sentence of death. A rhetoric that sets up the pleasure of its audience as its standard ultimately appeals to the passions of its listeners, not necessarily their best interests. ${ }^{6}$

Even Mambrès, whose intentions are above suspicion, must adapt his eloquence to the restrictions imposed by discretion. For example, in his efforts to save the bull from Amasis' wrath, he discreetly adapts his arguments to his audience and sets bounds on his objectives: "Le sage Mambrès ne voulut point choquer l'opinion du roi et du conseil" (21: 494-95). Instead of attempting to gain a pardon for the bull who was accused of bewitching the princess, he only aims at postponing the date of the execution, citing an excuse designed to appeal to the piety of the king - they should delay until a new god-bull is named in Memphis. In doing so, he invents a sort of prophecy of his own to which he adds a liberal dose of courtly flattery. "O roi! vivez à jamais. Le taureau blanc doit être sacrifié, car Votre Majesté a toujours raison; mais le Maître des choses a dit: 'Ce taureau ne doit être mangé par le poisson de Jonas qu'après que Memphis aura trouvé un dieu pour mettre à la place de son dieu qui est mort'" (21: 504). This discreet eloquence is only effective in so far as it uses ad hominem arguments that do not merit this closet deist's own adhesion, and even then its goals are limited. ${ }^{7}$ As Amaside reminds Mambrès bitterly, he is unable to soften the heart of the king with words alone: "Eh bien! mon cher Mambrès, lui dit-elle, vous avez changé les eaux du Nil en sang, selon la coutume, et vous ne pouvez changer le coeur d'Amasis mon père" (21: 509).

Even though the eloquence of Mambrès is clearly superior to that of the prophets or even the serpent, it does not reach the ideal dreamed of by Voltaire. ${ }^{8}$ How could it be otherwise in a courtly setting where discretion, whether silence or flattery, rather than open truth, was the order of the day? Voltaire had summed up this requirement of discretion in L'Indiscret where he had noted that at court, "L'art le plus nécessaire / N'est pas de bien parler, mais de savoir se taire" (2: 248). Appropriately, in Le Taureau blanc the full use of speech is restored only when the characters leave behind the constraints of the court. Amaside does not drop the mask of discretion and openly defy her father until she has crossed beyond the boundaries of his kingdom: "Mon cher père, allez couper le cou à qui vous voudrez; mais ce ne sera pas à moi" $(21: 511)$. At this precise moment, when for the first time someone dares address the king frankly, the seven years of the metamorphosis of Nabuchodonosor are completed, and he recovers first his voice and then his human form.

Likewise, in the regime of Louis XV where liberty of expression was also frustrated, the true "art de bien parler," the most authentic eloquence, was too dangerous to practice. Like Amaside, Voltaire had left the court, even if he could not bring himself to establish himself permanently outside of France, choosing instead to hover on the Genevan border at Ferney. Fortunately, the path of the "discrétion convenable" recommended by Mambrès remained open. For eloquence, this meant that the speeches which Voltaire acknowledged publicly such as his 1746 Discours de réception upon entrance into the Académie française are guarded. His most forceful eloquence had to take refuge in the world of fiction. It is in the Blueridge Mountains of Virginia that Freind's oratory in the Histoire de Jenni brings back his son to virtue and converts the atheist Birton, and Voltaire sets his Quatre Homélies sur la religion of 1765 in London. Only in a fictional setting could the philosopher display the full power of the enlightened word. His eloquence must imagine itself far from Paris to be free.

\section{III}

In Le Taureau blanc Voltaire brings into play a second mode of persuasive discourse, in the form of the narratives which Mambrès and the serpent relate to console the princess. However, Amaside rejects the Old Testament stories of the serpent in a sweeping critique that attacks them as boring, lacking verisimilitude, taste, and morality. An elitist brand of discretion is especially prominent in her capsule sum- 
mary of the ideal conte that appears at the center of her tirade: "Je voudrais surtout que, sous le voile de la fable, il laissât entrevoir aux yeux exercés quelque vérité fine qui échappe au vulgaire" (21: 506). In this formula Voltaire offers perhaps his most complete description of the conte philosophique since he alludes to the message ("verite fine"), the mode of discourse ("le voile de la fable"), and to its public ("yeux exercés," "qui échappe au vulgaire"). It would place too heavy a burden on this formulation, which is situated within a broad attack against Old Testament narrative, to expect that it should provide an adequate definition of all Voltaire's performance as a conteur. Just the same, if we examine these components in light of the discretion Voltaire used in his philosophic propaganda we can better understand how the conte can be seen as his own fable of discretion.

In fact, Voltaire saw fable, or at least Aesopian fable, as a discreet form of discourse. In his article "Fable" Aesop's tales are presented as a medium which the weak, obliged to "se garantir des forts autant qu'ils peuvent" (19:61), employ to conceal their thoughts from their masters: "Il est vraisemblable que les fables dans le goût de celles qu'on attribue à Ésope, et qui sont plus anciennes que lui, furent inventées en Asie par les premiers peuples subjugés; des hommes libres n'auraient pas eu toujours besoin de déguiser la vérité; on ne peut guère parler à un tyran qu'en paraboles, encore ce détour même est-il dangereux" (19: 59). There is certainly an element of Aesopian caution in Voltaire. For example, in public works like Mahomet or $\mathrm{Al}$ $z i r e$, the imaginary action on the stage is often a veil that allowed him to allude to religious issues which otherwise would have been off limits.

The contes, however, make fewer concessions to the official ideology; their fictional elements in no way diverted the authorities from recognizing their subversive nature, and thus even the occasional permission tacite foolishly granted to a work like L'Ingénu was quickly withdrawn. The clandestine distribution of the contes, and above all the fact that Voltaire refused to acknowledge them publicly, freed him from the need to disguise his criticism from the officials charged with monitoring the book trade by using some fictitional screen a la Esope. Yet while the fiction found in the contes is only one of the many genres Voltaire cultivates in his clandestine propaganda, it is in many ways his most successful. As we shall see, this is because the particular Voltairean brand of fable is uniquely suited to the public he addressed as well as to the targets against which his philosophic propaganda was aimed.

But if the discretion offered by the fable of Voltaire's conte philoso- phique is not Aesopian caution, where does it lie? Amaside's description of an audience composed of those with "yeux exercés" and her references to "quelque vérité fine qui échappe au vulgaire" suggest that the genre, at least as she conceives it, is the aristocratic counterpoint of Aesopian fable. If Aesop's fables are the expression of popular wisdom using fiction to disguise the truth from tyrannical rulers, does a conte by Voltaire embody an esoteric truth reserved for an elite and from which "le vulgaire" is excluded?

Two views of Voltaire's audience come into play, one which sees it as primarily composed of aristocratic inities, and the other as encompassing a wider public. The first view has recently been summed up by $H$. A. Stavan. "The initiés all use the same or very similar turns of sentences, expressions and allusions. The social milieu of the salon predominates and shapes this language. For the initiés it was certainly one of the greatest attractions to understand the sous-entendus of the letter-writer and author for this flattered their vanity whereas he used the jargon learned partly from them. He wrote his tales for them foremost and only in second place for the general public (the lower middle class)." ${ }^{\prime}$ Stavan acknowledges his debt to the concep of Voltaire's audience as a series of concentric circles which Geoffrey Murray identified through his analysis of the correspondence of the period of Candide. Murray found that Voltaire had groups of initiates, intimate correspondents, to whom he offers the first fruits of his writings and who share with the master a language of personal allusion and above all a knowledge of the multitude of roles (jardinier, vieillard laboureur, militant, etc.) which Voltaire constantly adopts. At times Voltaire accompanies the printed texts with letters that act as keys directing his intimates to certain resonances of the text; in any event, their contacts with Voltaire position the inities to grasp references which readers not in the know might miss. ${ }^{10}$

On the other hand, Roland Mortier, who studied the tension found among all the philosophes between their zeal for enlightenment and their uncertainty about to whom and how this message should be addressed, minimizes the tendency toward what he calls "esotérisme" in Voltaire. Mortier does concede that Voltaire gives widest diffusion only to his religious and moral ideas-his desire to see Christianity replaced by natural religion: "Voltaire distingue, sans le dire toujours expressément, entre les vérités qu'il est urgent de divulguer et celles qu'il convient de réserver au 'petit troupeau' des gens de "la bonne compagnie." Still Mortier concludes in favor of a much broader audience: "Au fond, Voltaire n'a cessé d'écrire pour le grand public, sinon peut-être pour les cordonniers et les servantes, 
et encore! Le tout est de s'entendre sur le processus et le rythme de cette diffusion." 11

These views of Voltaire's audience are not mutually exclusive, and the notion of discretion can help us discriminate between the strategies Voltaire uses in dealing with his various publics. First, the discretion of the contes is not the form we saw in the analysis of courtly eloquence where speakers use some measure of silence to conceal their true thoughts or misrepresent them with lies or flattery. Nor is it the Aesopean caution that uses fiction as a mask to allegorize some "vérité fine;" by adopting the discretion of clandestine distribution, Voltaire was freed from the need to disguise the "vérités" he dealt with from the censors. Yet the discretion of that clandestinity posed certain dilemmas at the same time. Rather than deny his "vérité" by disguising or deforming it, Voltaire denied authorship, but in doing so violated the bond of congruence that links speaker and utterance. Thus if Voltaire manages to assuage the established authorities charged with censorship and protect himself by publicly denying paternity of his works, it is, in a very real sense, at the price of a measure of his own identity.

However, his relationship with his most intimate readers, his initiés, allows him compensation. Even if he publicly denied a work, they could recognize his signature in his stylized disavowals. Indeed, with the initiés, he fostered an aura of connivance so that the text was for them testimony that they belonged to a chosen elite thanks to the network of allusions they shared with him through their correspondence. The implication is that among members of this inner circle there was no need for discretion since there are no secrets among friends. Discretion is rather directed by this self-conscious elite against outsiders. Thus, on the one hand, withholding his identity from the state's officials is justified: after all, he has in any case revealed it to those who count, the initiés. On the other hand, this discretion implies an aristocratic scorn for another group of outsiders, "le vulgaire" of Amaside, who are pictured as unworthy of the secrets of the elite.

Nonetheless, this concept of Voltaire's audience does not necessarily transform a work like Le Taureau blanc into a code that is indecipherable for the noninitiates, like the "symboles de l'antiquité" which Voltaire mentions in the article "Emblème" as reserved exclusively for a privileged minority (18: 520). Voltaire's relation to the readers of his contes beyond the inities might be thought of as a sort of calculated indiscretion. The initial public may be the aristocratic insiders, exemplified in the case of Le Taureau blanc by the readers of Meister's
Correspondance littéraire which was reserved for princely subscribers and where the tale first appeared in late 1773 and early 1774 . However, from the beginning, a much wider diffusion of the conte was calculated as seen in the good number of editions which followed in late winter of 1774. Indeed, Voltaire manages to flatter all segments of his audience. The initiates can take pleasure in the fact that the first fruits are reserved for them, while the broader public in this hierarchical society is delighted to be let in on what passes for an interchange among the elite.

But the best indication that the indiscretion involved in reaching this wider audience is calculated rather than real can be seen if we examine what Voltaire requires from his readers. A letter to De Lisle who couriered Le Taureau blanc from Ferney to Meister, the Parisian editor of the Correspondance litteraire, is revealing. De Lisle was also in contact with Mme Du Deffant, a longtime correspondent of Voltaire who was afraid that the conte would not please her: "Je ne sais si vous l'amuserez avec vôtre boeuf, car il faut être un peu familiarisé avec le stile oriental, et les bêtises de l'antiquité, pour se plaire un peu avec de telles fadaises, et Madame Du Deffant ne se plait guères à cette antiquité respectable. Je n'ai jamais pu lui persuader de se faire lire l'ancien Testament, quoi qu'il soit à mon gré plus curieux qu'Homère" (Best D. 18583). Even though Mme Du Deffant counts among the more intimate correspondents of Voltaire, the knowledge of scripture and ancient history he expects from his reader is accessible to a much wider audience. The Bible, of course, is always available, but Voltaire has in mind not so much indiscriminate reading of the Old Testament as familiarity with the sections he considers curieux. Indeed, an acquaintance with rather obscure episodes he alludes to, such as the sexual tastes of Oolla, or the "confitures" of Ezéchiel (21: 502), which were the frequent butt of his ridicule, facilitates an appreciation of Le Taureau blanc.

Yet a reader need not be an initie like Mme Du Deffant to be acquainted with these points of scripture. The many facéties in which he picks apart the Bible, published since his installation in Ferney, furnished a less intimate reader with a course of directed readings in Voltairean exegesis. In a sense, the fact that these works were available to any reader who took the trouble and expense to procure Voltaire's clandestine propaganda is an indication of how the effective circle of initiés, at least as far as his religious interests are concerned, had been expanded by the 1770 s by dint of frequent repetition. The allusions to Constantinople, the vieillard, etc., in the correspondence, which according to Murray add resonance to Candide for the initiés 
have been replaced to a large extent by the much more widely diffused biblical allusions found throughout his propaganda and crystalized in this conte. The fact that the saws have become common currency explains some of the poor reception accorded by the initiés to such later works. Mme Du Deffant complains that Voltaire offers nothing new: "Il fait depuis $\bar{q} \bar{q}$ temps un bien plat usage de ses talents. Je ne comprends pas quel projet il a eu en composant son conte du Taureau blanc: ce ne peut être que pour mettre au même niveau la Bible et la fable. Cela valait il la peine d'écrire?" (to De Lisle, 24 October, 1773, Best. D. 18596). This is, in a sense, a protest against Voltaire's indiscretion in sharing his "vérité fine" with a wider audience. Once outsiders have been let in on the game, the intimates begin to lose interest.

But what Voltaire requires chiefly of his reader is not so much knowledge of a code gained either as an intimate correspondent, as a frequent reader of his propaganda, or even from general knowledge of scripture acquired independently. The elite reader differs from "le vulgaire" of Amaside above all by sharing the "petit fonds de philosophie" which Sadi attributes to the sultana Sheraa in the dedicatory epistle of Zadig (21: 32). This elite is characterized by its open critical mind, and by being already won over, at least in part, to enlightenment. Voltaire does not exclude completely those he calls in a letter to Marmontel "les hiboux" with "leur haine pour la lumière" (Best D. 11667), but rather than convert the devout, he seeks to influence those who already lean towards enlightened values. This elite is distinguished from "le vulgaire" by its willingness to discern that there is more to the conte than the whimsical adventures of the plot. "Le vulgaire" is not so much those who cannot decode the "vérite fine" as those who do not choose to do so, preferring to be amused alone. For them, the fanciful intrigue of the tale is a veil of entertainment they have no desire to lift.

IV

"Les voiles de la fable" do not exist to conceal the "vérité fine" from some official censor or the unworthy masses any more than they exist to merely provide entertainment for the reader. Voltaire's unique brand of fable is rather a particularly apt instrument for fostering the critical spirit he prized, a fact we can better appreciate if we examine the fable in the context of the range of eighteenth-century meanings of the term. ${ }^{12}$ In its most fundamental sense, fable is fiction. It is an account of events presented as false, "le récit des faits donnés pour faux" (19: 346), in contrast to historical accounts that purport to relate events faithfully. Voltaire often refers to two particular forms of fiction, also identified as fable. We have already noted his reference to Aesopian fable. Fable could also refer to what we today label myth or legend. Winnowing authentic history from the mass of ancient legends that passed for history had long been part of the philosophic enterprise. Voltaire was especially sensitive to the fact that fable in this sense had often been used to convey moral or religious doctrine. ${ }^{13}$ Allegorical interpretation of pagan myths allowed them to be used as ethical instruction; Christian dogma itself is prefigured in the Old Testament and embedded in the events of the life of Christ. Voltaire, who dreamed of a purified religion with fewer concessions given to man's anthropomorphic tendencies, addressed the issue of using fable or legend as a bearer of truth in the article "Fraude" of the Dictionnaire philosophique, where the ideal of indoctrinating the masses in the central principles of moral law without recourse to myth or legend is defended: "on peut enseigner la vérité au peuple sans la soutenir par des fables" (19: 207).

Whatever success Voltaire might have had in propagating the core tenants of his deistic credo-the existence of God and the reality of natural law-without embodying them in an imaginative frame of fable, his own personal form of fable, the conte philosophique, was an especially effective medium for denouncing the doctrines of his enemies. Voltaire objected to the sacred history of the Infâme found in the Bible because it satisfied him neither as true history nor as fable capable of bearing some moral interpretation. The Old Testament for him was a web of improbabilities; the events it recounts are so mixed with legend and preposterous happenings that they could not be considered an authentic history of the past. But the scriptures fail as well as legend or myth because they are so filled with cruel or immoral happenings that it is often difficult to read into them any edifying lesson. The Bible is "ce détestable amas de fables qui outragent également le bon sens, la vertu, la nature, et la Divinité" (26: 212).

Le Taureau blanc thus denounces the Old Testament as a fable or myth of the worst sort. Voltaire's method, however, is far from the one used in a work of eloquence like Le Sermon des cinquante, where he ponderously judges scripture against two of the same standards used in this conte-vraisemblance and moral value. In Le Taureau blanc rather than examine the Hebrew histories with discursive argumentation, he merely juxtaposes a fable of his own invention with the 
personages of scripture. Voltaire's own fanciful version of Egyptian legend is not presented as an alternative to the history the Church recognized; in fact, Voltaire assumes that the reader only considers the pagan stories as fiction. It is the juxtaposition of the two that reduces the Hebrew accounts which are supposedly inspired by God to the level of the mythologies of other ancient peoples. Or more precisely, the Hebrew stories come off as inferior versions of the legends that infested the ancient Middle East. To this end, the Hebrew prophets are not presented as complete impostors. They are recognized as colleagues of the Egyptian sage Mambrès and share the same magical powers; however, they are less urbane, less successful, and far less wise. Similarly, Voltaire uses a character of his own creation, the heartless despot Amasis who condemns his daughter to death rather than break a vow, in order to highlight what Voltaire considers the barbarous morality of the Old Testament deity by drawing attention to Jepthe's sacrifice of his daughter to fulfill a vow to God. The story of the Fall is ridiculed by the parallelism between Amaside and Eve: the well-meaning serpent is less to blame for leading Amaside to commit the crime of pronouncing her lover's name than is her father who had established such an absurd taboo.

This strategy of destroying traditional myths with fables of his own invention that Voltaire directs against scripture in Le Taureau blanc works equally well against other widely accepted beliefs which have at tained the status of cultural icons and is at the heart of his critical method in the contes. ${ }^{14}$ Beginning with his first conte, Micromégas, in fact, he had aimed it at other myths of his day. In one of the most elegant discussions to date of Voltaire's use of fable, Oscar Kenshur proposes what he calls "counter-hypothetical fictions" as the basis of that first tale. ${ }^{15}$ Such a counter-hypothetical fiction, "while making no truth claims of its own, undermines the plausibility of the original hypothesis" (p. 45). In Micromégas, according to Kenshur, "instead of opposing man's complaints about his limitations (and the implicit assumption that he could be happier than he is) with the positive metaphysical claims of the Discours [sur l' homme], that everything is as it must be, and that our limitations are necessary, we have a counterhypothesis, according to which those imaginary beings that we imagine to be better off than ourselves see themselves as equally shackled with limitations" (p. 49).

Although Kenshur specifically refuses to claim "that Voltaire's conte philosophique is an intrinsically counter-hypothetical genre" (p. 50), I think an argument can be made that the juxtaposition of official myth with Voltaire's own fable is at the core of the critical enterprise in the contes, and that in large measure it provides their narrative coherence as well. In Le Taureau blanc, the plot centers around the consequences of Amasis' arbitrary taboo against uttering the name of his conqueror, which, as we have seen, provides numerous parallels with Voltaire's notion of the cruel Hebrew god. In Candide the action is structured around a parody of fictional genres with happy endings, whether the quest for a lost lover or the novel of adventures through which Voltaire satirizes optimistic visions of the world which minimize the presence of evil. In L'Ingénu he shows that the vaunted civilization of Europe has as much need of the sound judgment of the noble savage as the noble savage needs the experience accumulated over the centuries on the old continent. The focus of Le Taureau blanc, limited primarily to subverting Old Testament discourse, allows this strategy of juxtaposition to be perceived more clearly than in works like Candide where complexity of the issues raised can obscure the fundamental pattern. Such an exercise in critical reading constitutes the real "verité fine" of Voltaire's fable. It also explains why the philosophic storyteller wins out over the philosophic orator in his clandestine writings. In the long run, fiction with its base of an imagined action serves Voltaire's satiric "vérité fine" more effectively than eloquence, even if eloquence with its affinity with argumentation seem's more direct, and somehow more philosophic. If one compares, for example, the Sermon des cinquante, which like Le Taureau blanc is aimed against the Bible, the advantage of the ironic method of the conte is clear. The solemn tone of the Sermon may be more effective in establishing respect for the positive elements of Voltaire's deism, but in terms of the two works' subversive dynamics, the conte scores the same points as the Sermon against the immorality and implausibility of scripture, but in a more engaging, if not more telling way by leaving it to the readers to make explicit the "vérité fine" themselves.

If Voltaire adapted his discourse so successfully to the requirements of discretion it is perhaps because a fundamental tension in his thought impelled him to remain discreet. His militancy against the Infâme was tempered by a political and social conservatism. He placed his hopes on royal absolutism as the ultimate promoter of enlightenment, and although he envisaged a society with more personal liberty and where the rule of law would be respected, he did 
not contemplate upsetting radically the prevailing social arrangements. Unwilling or unable to acknowledge that the monarchy could not disintangle itself from the Church, he was forced into a stance of discretion. To speak his mind publicly against the Infâme would call down upon him the wrath of the civil authorities he struggled not to alienate. Not that he was unaware of the fragility of enlightenment that depended on absolutism. Witness his own experience with Frederick the Great, Louis $\mathrm{XV}$, and Catherine of Russia, none of whom fulfilled his expectations about how a philosopher-prince should reign. In his late fiction, even when he tries to portray an ideal ruler, there is almost always a note of doubt impinging on the paean as seen in the refrain, "Vive notre grand roi, qui n'est plus boeuf" which closes the portrait of Nabuchodonosor in the last paragraph of Le Taureau blanc. On the surface, the description of the king of Babylon reigning over a vast empire with peace and justice seems to validate the concept of enlightened absolutism. But the fact that this curious acclamation becomes a tradition in Babylon reminds the reader on further reflection that kings are singularly susceptible to being deceived by their entourage, and that even the exemplary rule of Nabuchodonosor is more an exception than the norm.

Voltaire's discretion is thus just one manifestation of a powerful impulse toward accommodation with the powers-that-be to be found throughout his works, but which is especially evident in the contes. From Ituriel's "Tout est passable" (21: 16) in Le Monde comme il va to Candide's garden, from the Ingénu's socialization into the army of Louvois to Amaside's passivity in the face of her father's absurd sentence, Voltaire's characters prefer to adapt themselves to the status quo, even if they remain ideologically undaunted.

A comparison with Rousseau can be instructive at this point. The theoretical deism of both men was quite similar, as Voltaire's high regard for the Profession de foi du vicaire savoyard shows, but since the Citizen of Geneva placed no hopes in the French monarchy and was profoundly distrustful of the aristocracy, he hardly felt bound by the same requirements of discretion as Voltaire. He insisted on signing his works, even those like Emile that contained material thoroughly offensive to the Church. Indeed, Rousseau was forced out of France for this indiscretion against the gentlemen's code regarding permissions tacites. ${ }^{16}$ Voltaire, on the other hand, chose the path of discretion by publishing clandestinely, and above all anonymously. Thus Voltaire's discretion allowed him to assert intellectual revolt without suffering the extreme consequences that Rousseau brought upon himself by openly avowing Emile. Yet it was by refusing the conventional discretion of his day which limited free expression that Rousseau created the most potent eloquence heard in eighteenth-century France.

Voltaire seems to have recognized that fiction adapts itself much better to the requirements of discretion than of eloquence. In a letter to Marmontel, in which he advises the younger writer who was famous for his Contes moraux to add contes philosophiques to his repertoire, Voltaire points to the potential of the genre as a discreet mode of discourse: "Vous devriez bien nous faire des contes philosophiques, où vous rendriez ridicules certains sots, et certaines sotises, certaines méchancetés et certain méchants; le tout avec discrétion en prenant bien vôtre temps, et en rognant les ongles de la bête quand vous la trouverez un peu endormie" (Best D. 11667). Voltaire's achievement was to turn fable against the fables of authority. He expropriated the conte, a form of fable that normally sought only to amuse, or in political terms to divert the readers' attention from the restraints on free expression by offering an escape into the world of fantasy. In Voltaire's hands, this discourse of diversion became persuasive fable that unmasks the mythic fables of the powerful. The amusement Voltaire proposes is above all philosophical, the delight that his readers/accomplices discover in using their critical faculties to expose error and stupidity.

Thus le vulgaire of Amaside's definition is not so much those readers who lack some insider's information available only to the experienced eyes of the initiés as those who refuse to assume the critical frame of mind every reasonable reader is summoned to assume. If Voltaire chose "le voile de la fable," it is not so much to trick the censors or to mystify the masses as because fiction, as an imaginary story, can become counterexample revealing the portion of the imaginary in the official fables. The conte may be a less direct mode of discourse than eloquence, but, because it is more discreet, it is a more effective instrument for a philosophe in a regime where discretion was the via media between obsequious acquiescence and the defiance that could lead to expulsion.

NOTES

1 The point of departure for any analysis of Le Taureau blanc is the critical edition of René Pomeau (Paris: Nizet, 1957). Other studies that treat the conte will be mentioned in passing. Two of the best are Maureen F. O'Meara, "Le Taureau blanc and the Activity of Language," Studies on Voltaire and the 
Eighteenth Century 148 (1976): 115-75, which analyzes the conte in great detail in terms of various eighteenth-century theories of language, and Douglas A. Bonneville who discusses the book as a highly self-conscious work in Voltaire and the Forms of the Novel, Studies on Voltaire and the Eighteenth Century, vol. 158 (Banbury: The Voltaire Foundation, 1976) p. 114. The Correspondence is cited from the definitive edition in the Besterman Complete Works of Voltaire, 51 vols. (Oxford: The Voltaire Foundation, 1968-1977). All other references to Voltaire's writings are cited from the Moland edition of the Oeuvres completes, 52 vols. (Paris: Garnier, 1877Moland edition of the Oeuvres com unless otherwise indicated.
1882)

2 One of the few commentators to point to the political implications of the conte is Hadyn T. Mason, "A Biblical 'Conte Philosophique,' Voltaire's Taureau blanc," in Eighteenth-Century French Studies: Literature and the Arts, ed. E. T. Dubois (Oriel Press: Newcastle upon Tyne, 1969): "What counts more than all these marvellous and fairy-tale metamorphoses is the reality of human happiness, supported and encouraged by the conduct of a good and wise king" (p. 68). My reading stresses the consequences for discourse of the fact that such wise and good rulers are the exception rather than the norm.

3 For the evolution of this topos in the eighteenth century see Jean Starobinski, "Eloquence and Liberty," Journal of the History of Ideas 38 (1977): 195210.

4 Pomeau, p. 65.

5 La Bible enfin expliquée makes an interesting parallel between the Hebrew prophets and Greek demagogues: "les prophètes étaient chez la nation juive ce qu'étaient les orateurs dans Athènes; ils remuaient les esprits du peuple. Les orateurs athéniens employaient l'éloquence auprès d'un peuple ingénieux; et les orateurs juifs employaient la superstition et le style des oracles, l'enthousiasme, l'ivresse de l'inspiration, auprès du peuple le plus grossier, le plus enthousiaste, et le plus imbécile qui fût sur la terre" (30: 246).

6 The serpent's ultimate appeal is to the passions. Voltaire notes elsewhere that for the Church fathers the serpent of the Garden of Eden was "une expression figurée qui peint sensiblement nos désirs corrumpus. L'usage de la parole . . . est la voix de nos passions qui parle à nos coeurs" (26 339). Certainly the net effect of his intervention with Amaside is not to calm, but to excite her passion.

7 This passage from the Dictionnaire philosophique ("Apis") makes clearer the significance of Mambrès' hidden deism: "Le boeuf Apis était-il adoré à Memphis comme dieu, comme symbole, ou comme boeuf? Il est à croire que les fanatiques voyaient en lui un dieu, les sages un simple symbole, et que le sot peuple adorait le boeuf" (18: 286).

8 For a description of the potential of authentic eloquence see Thomas $\mathrm{M}$. Carr, "Voltaire's Concept of Enlightened Eloquence," Nottingham French Studies 19 (1980): 22-32
9 H. A. Stavan, "Are Voltaire's tales narrative fantasies? A reply to Wolper," Studies on Voltaire and the Eighteenth Century 215 (1982): 283.

10 Geoffrey Murray, Voltaire's Candide: The Protean Gardener, 1757-1762, Stud ies on Voltaire and the Eighteenth Century, vol. 69 (Geneva: Institut et musée Voltaire, 1970), pp. 36-38, 180-87.

11 Roland Mortier, "Esotérisme et lumières," in Clartés et Ombres au Siècle des lumières (Geneva: Droz, 1969), p. 76.

12 For a comprehensive examination of the semantic field of such terms as fable, conte, roman, nouvelle based on definitions given in eighteenth-century dictionaries, periodicals, and literary manuals, see Nicole Gueunier, "Pour une définition du conte," in Roman et lumières au XVIII siècle (Paris: Editions sociales, 1970), pp. 422-36. See pp. 426-28 for the opposition fable, conte.

13 He treats moral and dogmatic interpretation of scripture in the Homélie sur l'interprétation de l'Ancien Testament, 26: 338-49. As might be expected he has no use for interpretations that see in each event of scripture "un emblème historique et physique." It is much better to "tirer de tous les faits des instructions pour la conduite de la vie" (26: 346). He deals in more detail with the issue of Hebrew and Christian fable in the Examen important de Milord Bolingbroke, (26: 195-300).

14 A number of critics recently have pointed to Voltaire's use of fable. Jean Sareil groups together all short didactic texts that Voltaire variously called diatribe, conte, fable, apologue, historiette under the label apologue, "Les Apologues de Voltaire," Romanic Review 67 (1977): 118-27. "L'apologue est donc toujours militant chez Voltaire, en ce sens qu'il vise un but immédiat auquel tous les effets littéraires sont subordonnés. La plupart du temps il est simple et naif, mais la simplicité et la naiveté sont des procédés comme la sophistication" (p. 127). Jean-Michel Raynaud underscores Voltaire's denunciation of human fabulation by means of fiction in "Mimésis et philosophie: approche du récit philosophique voltairien," Dix-Huitième Siècle 10 (1978): 407. Paul Lecocq assimilates Candide to fable in "Un apologue de l'éternel séisme: Candide," Informations littéraires 35 (1983): 77-78. One might also add P. C. Mitchell who shows how Voltaire manipulates inconsistencies and absurdities to develop a critical awareness in the reader in "An Underlying Theme in La Princesse de Babylone," Studies on Voltaire and the Eighteenth Century 137 (1975): 31-45.

15 Oscar Kenshur, "Fiction and Hypothesis in Voltaire," The Eighteenth Century: Theory and Interpretation 21 (1983): 46.

16 For an account of the affair see Lester G. Crocker, Jean-Jacques Rousseau The Prophetic Voice (New York: Macmillan, 1973), 2: 118-27. Crocker notes, "If Rousseau had followed the usual practice of anonymous publication followed by denial of authorship, he would probably not have been personally molested" (p. 127). 